\section{Submarine Light and its Biological Importance}

SINCE submarine light was made accessible to accurate measurements through the development of the photo-electric cell, sub-surface light measurements have attracted an increasing number of workers in different countries. The vast importance of subsurface daylight as a controlling influence on the photosynthesis of phytoplankton and on the movements of zooplankton has made marine biologists realise the necessity for observing and correlating this factor with phytoplankton growth, with the migrations on zooplankton and of fishes, and with the abundance of year-classes of the latter At the 1936 meeting of the International Council for the Exploration of the Sea, a special session was devoted to "Submarine Daylight, its Measurement and Biological Effects". The biological importance of extensive observations on sub-surface illumination was especially emphasised by F. R. Russell and G. L. Clarke, both specialists on marine biology, the other authors considering more particularly the physical aspects of the observations.

H. H. Poole dealt at the meeting with the various sources of error inherent in such measurements, and with the precautions necessary for their reduction or elimination. C. L. Utterback described a long series of measurements on the penetration of various spectral bands in Pacific waters, carried out with apparatus in some respects in advance of any used by other workers. The important question as to the unit of light intensity to be recommended for workers in the field was raised by A Ångström, who pleaded for the cal./sq. cm./min. unit used in studies of solar radiation in lieu of the less well-defined photometric unit, lux or metre-candle, which is at present widely used. $\mathrm{He}$ suggested a method of standardisation by means of sunlight with suitable pyrheliometer measurements. H. Pettersson de scribed his work on the direct measurements of the transparency of sea-water to artificial light. This method enables variations in opacity to be rapidly and accurately examined. Messrs. Angström, W. R. Atkins (of Plymouth), Clarke, Pettersson, Poole and Utterback were appointed as a special committee for the purpose of working out definite proposals for instruments, methods of measurement, and choice of units, to be laid before the next meeting of the International Council in 1937.

\section{Congress on Photoluminescence}

AN International Congress on Photoluminescence was held under the auspices of the Institute of Experimental Physics of the University of Warsaw and the Polish Physical Society at Warsaw on May 20-25. The central theme of the invited papers and the discussions was the mechanism of production, interpretation and theoretical aspects of absorption, fluorescence, and phosphorescence spectra. Belgium, France, Germany, Yugoslavia, Latvia, Poland, Rumania and the United States were represented by the 149 physicists attending the congress. At the opening ceremony, the members were welcomed by the Polish Minister of Education ; and the President of the Polish Republic, who was himself a professor of physical chemistry, received the group at his residence. Papers read and presented at the Congress are being published in a forthcoming issue of Acta Physica Polonica.

\section{Control of Rabbits}

AN article on this subject in Nature of May 16 referred to D. G. Stead's book "The Rabbit in Australia" in which the use of 'Cyanogas' is advocated. Capt. C. W. Hume, honorary secretary of the Uni. versity of London Animal Welfare Society, which is acting as agent in Britain for Mr. Stead's book, informs us that 'Cyanogas' can be obtained from Messrs. George Monro Ltd., Waltham Cross, Herts, while 'Calcid' is supplied by the London Fumigation Co., Marlow House, E.C.4. A British product known as 'Cymag', having generally similar effects, can be obtained from Imperial Chemical Industries, Millbank, S.W.1. A fairly powerful pump is required and such pumps can be obtained from the above firms or from Messrs. W. J. Craven Ltd., 50 Port Street, Evesham, Worcestershire. Capt. Hume states that the prineipal obstacles to the control of rabbits are the reluctance of farmers to adopt a new and unfamiliar method and the difficulty of securing concerted action between neighbouring farmers. The following motion, drafted by the University of London Animal Welfare Society, for the appointment of a select committee was moved by Lord Merthyr in the House of Lords on May 14, and carried: "That a Select Committee be appointed to consider whether any measures, and if so what, ought to be taken for better protection of Agriculture and the land against the ravages of rabbits, and to what extent, if any, the prohibition of the use of Gin Traps would affect the attainment of the object aforesaid".

\section{Lily Year Book}

Tне Royal Horticultural Society's "Lily Year Book" for 1935 (from the Society's Office, Vincent Square, S.W.1. 5s. paper, 6s. cloth) is something more than a mere review of progress; some very fundamental contributions are set before its readers. It is perhaps not invidious to give pride of place to Dr. Fred Stoker's "List of Lily Names and Synonyms", as this is a very painstaking and complete attempt to reach orderliness and exactitude in lily nomen. clature. Nearly 540 species, varieties, forms and crosses have been considered, accepted names are indicated clearly, and synonyms are printed in italics. Dr. M. A. H. Tincker describes "Experiments with Lilies at Wisley", Mr. W. E. H. Hodson writes on the control of lily pests, and the late Dr. D. Griffiths, an American authority on vegetative propagation of lilies, is represented by an article on "Vegetative Propagation of Hybrid Lily Clons". Mr. J. Ingram ministers to seed propagation by a paper on "Development of Lily Seedlings". Geographical distribution is a fascinating subject, and articles upon the native lilies of western America (Mr. Carl Purdy), eastern Asia (Mr. A. D. Cotton) and Asia Minor (Mr. E. K. Balls) are included. Mr. T. Hay has 
reviewed "Some Lily Literature", while the various aspects of garden technique and the horticultural setting for lilies have called forth many articles, and inspired most of the plates. The volume is quite equal to the Royal Horticultural Society's high standard of literary production, and should commend itself to all who take delight in the beauty and skill of the garden.

\section{The National Physical Laboratory}

THE Report for 1935 is 249 pages in length and is published at 12s. It has the unfortunate duty of announcing the deaths of the first two Directors of the Laboratory. Other changes of staff have been few. At the silver jubilee of King George, medals were awarded to fifteen members of the staff for their distinguished work. The new photometry building has been completed, and it is hoped to make an early start in extending the acoustics building to meet the demand for information as to the sound insulation of floors. A new high-speed wind tunnel of the return flow type and one for investigating the effects of turbulence on larger scale models are under consideration. The general demand for assistance by industry has increased during the year. The provincial lectures on the work of the Laboratory have been continued, more than a dozen towns having been visited. Each department of the Laboratory gives an illustrated account of its activities in language which is not too technical for the average reader. A good example of the result of co-operation between several departments is the proof that the slip bands in a single crystal under stress contain disintegrated crystal fragments of size generally greater than $10^{-5} \mathrm{~cm}$. and dislocated grains generally greater than $10^{-4} \mathrm{~cm}$.

\section{Forestry in Great Britain}

Forestry, the journal of the Society of Foresters of Great Britain (9, No. 2, December 1935. Oxf. Univ. Press) opens with a presidential address to the Society by Sir Alexander Rodger in which he discusses the varying importance which forestry has attained in different countries. After alluding to the different types of areas set apart for the recreation of the public in the United States, Sir Alexander dealt with the position in Great Britain. There is at present an absence of a forestry sense; and owing to this absence the work of the Forestry Commissioners does not prove so easy to carry out as might otherwise be the case. The constitution of an informal committee composed of members of the Council for the Preservation of Rural England and members of the Forestry Commission was alluded to. It is hoped that this committee will help to disseminate a knowledge of the aims of forestry in Great Britain.

\section{Care of Children and After-care of the Injured}

WHEREAS arrangements for the supervision of the health of children up to the age of two years or thereabouts appear to be generally satisfactory, the Minister of Health does not consider that enough attention is being given in many areas to the health of young children between eighteen months and five years. The Minister has therefore issued a Circular (Circular 1550. London: H.M. Stationery Office. 1d.) directing that it is essential that in all areas there should be systematic periodical health visiting of those young children who are not in attendance at school, and making suggestions for 'toddlers' clinics' and day nurseries. A representative InterDepartmental Committee has also been appointed by the Minister of Health and the Secretaries of State for the Home Department and for Scotland to inquire into the arrangements made in Great Britain for the restoration of the working capacity of persons injured by accidents. This matter arose after consideration of a report upon the treatment of fractures issued in February 1935 by the British Medical Association.

\section{Czechoslovak Scientific Expedition to Iceland}

AN expedition to Iceland has been planned for this summer by a party of Czechoslovak men of science. The objects of the expedition include a geological and chemical study of the hot springs, geysers and volcanoes. The botanical members of the party, which is under the direction of Prof. Joseph Kunský, will make as comprehensive a collection of the flora as is possible during their visit. Film photographers are included in the party, and the taking of Nature study films constitutes one of the important objectives of this expedition.

\section{Giovanni Canestrini}

The first centenary of the birth of the eminent Italian naturalist, Giovanni Canestrini, was recently celebrated at Trent on the initiative of the Museum of Natural History and the Society of Studies of Venezia Tridentina, when an address was delivered by Prof. Pasquini. Canestrini was born at Revo near Trent on December 26, 1835. He studied medicine at Vienna under Hyrtl and Brücke and shortly after qualification in 1860 was elected professor of comparative anatomy and physiology at the University of Padua, where he founded a laboratory for bacteriology, and was the first teacher of this branch of medicine. In addition to translating almost all Darwin's books into Italian, he was the author of original works on the fish of Italy, the origin of man, the theory of evolution, a critical exposition of Darwin's theory, Italian arachnids and Italian acari.

\section{Dresden Meeting of the German Association}

THE German Association of Naturalists and Physicians (Gesellschaft Deutscher Naturforscher und Aerzte) is to meet this year in Dresden on September 20-23. There were earlier meetings in Dresden in 1826, 1868 and 1907. Dresden has been for long a city of fine arts ; its fame is founded on its picture gallery with the Sistine Madonna, its opera and its theatre. For more than a century it has been a nursery or scientific, medical and technical research. More lately it has become a city of public health, since the first international hygiene exhibition in 1911. 